\title{
Naam, Kaam, Gaam: Educating Women for Self- Employment, Cooperation and Struggle
}

\author{
Namrata Bali \\ Director, Self-Employed Women's Association (SEWA) Academy
}

The following is a detailed description of a training program offered by the SelfEmployed Women's Association (SEWA) Academy to introduce new members to the organization and its work. SEWA describes its main goals as "to organize women workers for full employment," by which it means "employment whereby workers obtain work security, income security, food security, and social security (at least health care, child care and shelter).” The organization works to achieve its goals "through the strategy of struggle and development. The struggle is against the many constraints and limitations imposed on them by society and the economy, while development activities strengthen women's bargaining power and offer them new alternatives." SEWA describes itself as "both an organisation and a movement," which is enhanced by "the sangama or confluence of three movements: the labour movement, the cooperative movement and the women's movement." SEWA also describes itself as a Gandhian movement: "Gandhian thinking is the guiding force for SEWA's poor, self-employed members in organising for social change. We follow the principles of satya (truth), ahimsa (nonviolence), sarvadharma (integrating all faiths, all people) and khadi (propagation of local employment and self-reliance)." In practical terms, SEWA carries out its strategy "through the joint action of union and cooperatives." As a trade union, it has nearly two million members, half of whom are in the organization's home state of Gujarat, India. It also operates or is affiliated with nearly two dozen sister organizations and cooperatives.

\section{Naam, Kaam, Gaam: Our Name, Where We Live, Where We Work}

The training sessions described below are intended to introduce members to the purpose of SEWA as a movement. Its principal objective is to help members realize their own self-worth. It starts, as do all SEWA activities, with women at the center of its concerns and then works out from there. Each woman is also encouraged, after having realized her self-worth, to take pride in the work that she does and in the contribution she makes to her home, her community, the wider society, and the nation at large. In this way each member learns to value herself not only as a person, but also as a worker and thus builds a solidarity with the other women workers like her.

Who Are We?

Having an identity as a worker has great significance in a worker's life, especially for women workers. A woman is generally defined in Indian society in relation 
to her position vis-à-vis the family, community, or society. She is identified as somebody's mother, daughter, wife, or sister, but not as a worker. Her contributions as a worker remain unacknowledged, her position always beneath that of others. A forty-year-old vegetable vendor named Kankuben Laxmanbhai Patni, who had been selling vegetables in Dariapur, Ahmedabad, for twenty years, shared her experience of being asked to introduce herself for the first time in the first ever session of the SEWA Movement Training in June 1992. Here is how she described her initial nervousness and the reasons behind it:

Nobody till now has asked me my name. Even if they have asked they have never cared to listen. Nobody remember my name, nobody calls me by my name. Even if they called out my name they distorted it .... But now, if somebody distorts my name, I immediately correct them.

[The] police call me by my handcart number-No. 308. My customers also never call me by my name and Address me as "Ben." After all, of what use is my name? In my neighbourhood my neighbours call me "Laxman's wife" or "the green-eyed one," as my eyeballs are green. Even, say in case of my mother-in-law, who is so old, nobody calls her by her name. Everybody knows her as "Laxman's mother." My sister-in-law is physically challenged and everybody calls her a cripple, but her name is Bhavna.

Children are given a name at birth, and the person who keeps that name is gifted with something by the family. But the value of the name ends there.... Nobody writes me a letter in my name. I have no register to sign, where I can put my name. I have no ration card in my name. Even the mill workers have registers with their names but not me. Even in the voter's identity card my name is spelled wrong.

I liked Beenaben's (our instructor) words that our name gives us an identity. It talks about our culture, our roots. It gives us respect, the fact that even if I am a woman I have a name. What if I am a poor, labourer woman, I have a name, a work and I want to tell it to the whole world.

Asserting one's own identity in terms of one's name, work, and address is a big step forward. Imagine if no one knew your name! SEWA led a campaign for identity cards from employers, which were to include the name, work, address, and photograph of the worker. The identity cards could be used as proof of identity in the absence of any other valid documentation, like ration cards, passports, and so forth. Having an ID card is very important for poor workers in the informal economy. Identity cards help to ensure that these workers get counted in the census, which in turn affects how the government budget is allocated. In the long run, by getting counted, their contributions are more accurately reflected in the national economy. For example, securing identity cards for bidi workers provided a more accurate count of their approximate numbers. Also, with a card they could avail themselves of various support services, like child care, health care, and social security. 
Providing an identity card to a woman worker also means giving her a new identity as a worker in her own right. She is given a space to belong. She is no longer only someone's mother, wife, or sister, but is a worker with a trade, such as vegetable vending, paper picking, printing, working in the salt pan, dairy producer, weaver, embroiderer, forest worker, bidi worker, and so forth. A woman with an identity as a worker is no longer a Harijan, an Adivasi (Aboriginal), a Hindu, a Muslim, a Vagri, Koshti, or a Telegu. A new identity is forged, which can change the way social ties are structured, help put an end to discrimination, and build bridges between women who are otherwise divided and separated from one another. The identity card can thus build solidarity. When one worker sees an identity card in someone else's hand, immediately a bond is established between them. They both unite as workers without any social or community barrier.

\section{Ourselves, Our World}

In June 1991 a group of twenty women leaders of various trades assembled in the training room for prayers at SEWA Academy to begin their two-day workshop on the SEWA Movement and their own role in it. Some women sat quietly and expectantly, as they had never participated in such a training session before. Others chatted and laughed easily, relieved from their daily routine of sewing garments, rolling bidis (small cigarettes), or mixing colors in the dyeing units - each struggling in her own way for a living. Some faces even revealed anxiety, probably wondering, "What is this training? What will I have to do? Will I be able to do it?" The Sarvadharm prayer put the group at ease immediately. Soon the upper floors of SEWA Academy were resonating with many voices of different cadences. The training had begun.

One of the trainers welcomed the participants and explained the first session. "We all have to stand up and introduce ourselves: our name (naam), where we live (kaam), and where we work (gaam)". She explained that all the women needed to listen very carefully to the introductions, as they would each have to learn and repeat the names of at least five of their colleagues before the exercise was complete. Gangaben, a head-loader, adjusted her sari and stood up with folded hands. The senior trainer then suggested, "We all are colleagues here, and there is no need for anyone to fold their hands in respect to anyone present. I also urge Gangaben to repeat her full name, including her husband's." Peals of laughter accompanied Gangaben's pronouncing her husband's name, Ramdas, as women traditionally never refer to their husbands by their names. It is part of a very strict code of dos and don'ts that women encounter within the family. Speaking the name of the husband, or, for that matter, anyone senior, is a sign of disrespect. Often, therefore, the wife's name is never spoken by her husband. She is instead referred to as so-and-so's mother. By speaking their husbands' names, it was hoped that the participants would overcome the social taboos against doing so. 
Following Gangaben's bold lead, one by one the other women stood up to introduce themselves. A few spoke confidently and fearlessly. But most were nervous, self-conscious, and inaudible. They fidgeted and adjusted their saris or dupattas and grinned nervously. Standing up and introducing themselves confidently, in front of a group, was something they had clearly never done before. Further, they simply could not remember each other's names. After a few confusing rounds of women introducing themselves and their worlds, the senior trainer then explained the importance of this apparently difficult first session. If the women did not respect themselves enough to articulate their own names or value their work enough to say what they did, proudly and confidently, then how could they expect anyone else to respect them or value their work? At this, several women nodded in agreement.

Moreover, the exercise also served to break barriers between the participants, who came from different castes, religions, and communities. Being required to remember the names of five other women around them enabled the participants to mingle with others whom they might not otherwise associate with or be allowed to see. It took an hour, from 11:45 a.m. to 12:45 p.m., for everyone in the group to learn the names of at least five other participants, and as the exercise dragged on, the senior trainer explained further:

As you don't remember each other's names you will remain as scattered beads. How can we make a necklace that binds us all together? If we don't know each other by name, if we do not understand the importance of this, then how will we help each other in times of struggle? We have to first learn to say our own names with pride, and then only will we be able to introduce our organization.

It was easier, however, for the women to remember each other's work than it was to say their names, about which the senior trainer was able to point out that they could still bond as workers, even if they did not value themselves as workers.

And this then made it possible for her to emphasize the link between the women's sense of their own importance and the value of their work. "Because we work and work hard," she said, "our country develops and is saved from debt. Women do so much work - they work for a living, earn for the country and manage their home. Women are workers, mothers, and homemakers. We should take pride in ourselves as self-employed working women." She could then also explain that by being self-employed, women in the group were not dependent on anyone for a living, that they made a living through their own hard work. The senior trainer's words seemed to make a lot of sense, and the women listened with rapt attention, some nodding in agreement.

The first session then concluded with each woman standing up yet again to introduce herself and to state where she lived and her work, which they all did, this time with a renewed courage. Moreover, each introduction was videotaped by Video SEWA to be used later in the workshop and for other purposes. None 
of the women had ever stood in front of a camera before. They were excited and nervous.

\section{Our Organization, SEWA}

The director initiated the session, explaining that SEWA was an acronym for their organization, the Self-Employed Women's Association. She then asked if anyone could explain the meaning of each word of the organization's name, but no one could. The facilitators then explained the name and pointed out that although SEWA means service, it is in fact a registered trade union and not a charity organization. She also discussed the term "self-employed," stressing that SEWA was not just any women's organization. It was an organization of poor, working women. The women stood to sing "SEWA No Bedo Paar" ("SEWA Overcome All Hurdles"), which described the different workers and trade groups of SEWA. The song ends by asking, "Why can't women be drivers, factory managers, tractor drivers and other such traders, where usually one only sees men?" The women clutched the song sheets and sang with gusto.

"We sing this song," the senior trainer said, "because we want to make our daughters inspectors, tractor drivers, and factory managers, just as in our song. ... We must educate our daughters to be all that we sing and dream about. Let our daughters not remain mere bidi rollers and head-loaders like us." A wave of approval swept through the group. The song was inspiring and informative. By singing it, the women were able to learn more about the broad categories of the SEWA membership, like hawkers and vendors, homebased producers, laborers, and service providers, as well as rural producers.

And with that the second session came to a close. Lunch together followed. Women who had not known each other earlier sat and ate together. Differences of community, language, religion, trade, and neighborhood melted away amid the clatter of the thalis (round platter) and the lively conversation. A oneness began to develop. The group was acquiring an identity of its own. The scattered beads were becoming a necklace.

\section{Gandhi's Life, SEWA's Inspiration}

After lunch, the senior trainer spoke about Gandhi's life and how the idea of Satyagraha was born out of Gandhi's personal experiences with the injustices of Apartheid in South Africa. She explained how, despite his commitment to struggle against injustice, he never developed personal enmity or ill will against his oppressors and always remained nonviolent:

This is what we have learned from Gandhiji, to fight with dignity and resolve against injustices, but without bearing ill will towards any human being. Gandhiji taught us that the means in any struggle or movement is very important. Thus in SEWA, too, we do not have hatred in our hearts for our oppressors or exploiters and their families. We do not believe in personal vendettas. 
A second important lesson learned from Gandhi, she went on, was his deep concern and commitment to Sarvadharma Samman, or religious tolerance. "[Gandhiji] studied all religions and drew much strength from all faiths. Similarly, we at SEWA propagate Sarvadharma Samman", the senior trainer explained. The women also heard about the simplicity of Gandhi's life. He had hardly any possessions and lived his life like the poor. Thus, SEW too emphasizes simplicity or Saadgi. "That is why we only use khadi," she explained. "It is simple and also gives employment to poor workers who spin the cotton thread and then weave it into cloth."

Finally, the trainer concluded by talking about what she described as "Bapu's special concern for women." She cited an incident that occurred in Champaran, Bihar. While leading a struggle against exploitative colonial indigo planters, Gandhi called a meeting. When no women came to this meeting, he asked his colleagues to find out why. They returned and said that the women could not come because they had just one sari each, which had to be washed and dried before they could come and attend the meeting. Gandhi was so moved by this incident that he decided then and there to wear only a loin cloth. "If my people are so poor that they cannot come to a meeting for lack of clothing, then I have no right to wear so much clothing," he argued. And thus, thereafter, he only wore a loin cloth - even when he went to England.

Tracing the origins of SEWA, the senior trainer went back to the 1917 founding of the Textile Labour Association (TLA) by Gandhiji and Anasuyaben Sarabhai, the daughter of a mill-owning textile magnate. They organized the mill workers, who then called a strike for the first time under their leadership. Thereafter, also for the first time in India, the mill workers and mill owners sat together and negotiated a settlement. The trainer explained how this was the beginning of negotiation and mediation practices that were still used in SEWA, which is thus rooted in a long tradition and history of struggle of workers based on Gandhian principles, which emphasize negotiation and mediation. The senior trainer then ended the session by teaching the group a new song "Gandhi Amaro Neta" (Gandhi, Our Leader).

\section{Drawing Together, Learning Together}

A drawing session followed. It started with a facilitator explaining how drawing was a simple exercise, that anyone can draw, and that the women were to draw whatever came into their minds when they heard the words "self-employed women." She distributed papers and markers to the participants. The women giggled. Several reactions from the trainees followed:

Farida: "You have successfully trapped us. What shall I draw?"

Shairunissa: "But I have never held a pen in my hand before. I don't know how to draw. I have watched my children draw, but that is all. We never have time to think of drawing. It is work, work, work - that is all." 
Gangaben: "I have never entered or seen a school in my life. But you are asking me to draw."

Despite the laughter and the reluctance, each woman took her paper and marker and found a spot to draw. Markers were grasped shakily at first but then with an increasingly firm hand. Another barrier had just been broken.

\section{Communicating with Each Other}

The last session of the day focused on the importance of clear communication. All the women sat in a circle. The facilitator explained that she was going to whisper a message to one of the women and then they were to whisper into the ear of their neighbor, and so on until the message went all the way around the circle and came back to its originator. There were some muffled giggles and some loud whispers. But the message was passed around the circle, and when the message got back to its origin, it was a distorted version of what it had been. This bought forth bouts of laughter, explanations, and accusations, as the women tried to find out where the message had gone wrong. They tried a few more rounds, with more giggles and more confused messages. The senior trainer then observed, "If we cannot even pass a simple message along accurately, how will we build our movement? See how much we have to learn?" "Yes," responded Bhanuben, an articulate young woman with fiery eyes, "This is why we fight amongst ourselves instead of fighting the injustices. We get all these wrong messages and rumors." And with this game the first day's training ended with the women walking in twos and threes, across the Ellis bridge next to the SEWA Academy, with their newfound sisters in struggle.

\section{Feedback}

There was a new spirit in the air as the women assembled for prayers on the morning of the second day. They were no longer strangers. The training the day before had made them open their hearts and minds to each other, and they sang together with new strength. The senior trainer then asked the women how they felt about the previous day's training. Did it make any sense? Did they learn anything new? What had they liked?

- "I liked what you said about women, because usually women are not considered important," volunteered soft-spoken Jadiben, who rolled hundred of papads every day for a living.

- "I taught my neighbours some SEWA songs," said Bhanuben.

- "I liked what you said about Gandhiji," said Kesarben. "Bapu always told the truth. His feelings about the poor were correct."

- $\quad$ "And I liked what you said about our daughters: that they should be educated and do something other than just majdoori (wage labor)," said 
Samuben, a wise, older woman who had spent her life toiling as a contract laborer.

- $\quad$ Shakilaben and Maniben, two vegetable vendors added, "All the women in our chaali said, 'Why don't you take us to the training. We also want to learn these new things."”

\section{Drawing Out the Lessons}

Next, while the drawings were pinned up for everyone to see, each woman had to explain what she drew. Murmurs went through the group. Clearly lots of mixed feelings regarding their creations were afloat. For many, it was the first time that they had ventured into the world of pen and paper. Here are some of the expressions that they shared:

- $\quad$ Shakriben: "I enjoyed drawing. I drew whatever came to my mind. I sell potatoes and onions so I drew vegetables."

- $\quad$ Sanuben: "I felt happy while drawing. I wanted to show my happiness. So I drew a kite, flying high in the sky."

- $\quad$ Tellamma: "I drew a house, my house. Since housing is so important for us I drew a house."

- Jikooben: "I drew a pappad (lentil cracker), as all in our union enjoy pappad. I also drew shakkapara (fried sweet dough), as when I roll papads and feel hungry, I eat shakkapara."

- Jashuben: "I drew Surya because when I get up every morning I pray to Surya, so that my day goes well."

- $\quad$ Bhanuben: "I have drawn a broom, duster, bucket, swabbing cloth, and other cleaning material because I am a cleaner. That is how I make a living."

- $\quad$ Farida: "I drew my sewing machine and clothes for sewing. These stairs symbolize SEWA - the stairs at SEWA and the tap for drinking water at the SEWA office. And I drew flowers because I sometimes make plastic flowers."

- Shakuntala: "This is my haathlari (handcart) and bales of cloth. This is how I am living."

- Bhadraben: "I tried to draw all the difficulties I face while rolling bidis."

- Jashiben: "I make files. So I have drawn files and scissors."

- $\quad$ Gangaben: "I also drew myself pulling a lari (cart). First my husband and I used to pull it together. But now he has died. So now I pull it alone."

- Jadiben: "I drew a kite because our lives are like kites - they just fly away. Then I drew a lotus because I feel our lives should bloom like a lotus."

- $\quad$ Shairunissa: “I didn't draw much because I feel my life is worthless. I was so afraid when I took hold of the pen that I simply could not draw. I felt that I was given a chance in life ..." 
The women's drawing brought forth their concerns, their beliefs, and their state of mind. Housing, food, and work present a constant worry for them and are thus reflected in their drawing of houses and so forth. Their identities were also greatly affected by their occupations - thus the drawings of their work equipment like handcarts, sewing machines, mops and cleaners, scissors, and so forth. The importance of the previous day's session also was reflected in the fact that they all clearly understood the value of their work in their lives and used it as a point of reference.

\section{Learning from Our Leaders}

Now the women were ready to see videos of some of SEWA's leaders and to discuss them. The first video focused on Kamla Dadge, an articulate, capable organizer of bidi workers, who rolled bidis herself until she became a union organizer. The women watched Kamla closely as she shared the story of her life, her struggles, and her determined resolve to organize other women like her. The facilitator then asked the women to respond to the following questions: "How did Kamlaben become a leader? Does she have any special skill?" Yellamma, herself a leader of bidi workers in Ahmedabad's sprawling Bapunagar neighborhood, responded that Kamlaben "can explain about organising and about SEWA to other workers." There followed a chorus of voices, all eager to share what they had learned from the video about Kamla. "She brings poor women's concerns and needs to SEWA," said Shairunissa. "She had to work very hard to be a leader," said another woman. "Kamla also had to solve women's problems, go with them to SEWA, to the bidi merchant, and to the government. She had to learn how to give appropriate answers to everyone with whom she works," said Bhanuben. "People trust leaders. Only if you have poor women's trust can you be a leader," said Samuben, a lively head-loader from the big, wholesale cloth market at Kalupur. "And leaders have to make sacrifices. They have to give time, put their work aside, and be at their colleague's sides at whatever time of the day they are required," said Samuben.

A picture of what made a leader of a SEWA movement was beginning to emerge. It was then time to see the other videos of SEWA leaders. A video of Maniben, a leader of the head-loaders and an old-timer of SEWA's executive council was next, followed by one about Rahimaben, a ready-made garment organizer who rose above a difficult family life to become an impressive leader. Then followed an interview with Kamla, a SEWA executive council member, and finally the women watched mesmerized as Taraben, who started out as an agarbatti (incense sticks) worker and was now a stalwart of SEWA Bank, explained how she was drawn to SEWA and became active in encouraging women to save their hard-earned money.

At this point the senior trainer then explained,

Our strength, our base [in 1991], is our membership of 300,000 self-employed women. This is also the poor from amongst whom SEWA's leaders emerge. One 
leader has 200 members with her. These leaders then form a trade Council which in turn elects an Executive Committee of 25 leaders. This committee of 25 leaders is SEWA's supreme decision making body. The trade group or occupation group that has maximum members also has maximum members ultimately in the Executive Council or Karobari. This is because membership and number of representatives to the Trade Council or Prathinidhi Mandal is very much linked. And this Mandal then elects the Karobari.

The women then began to understand the importance of increasing membership in a new light, and the facilitator added that the biggest challenge for the women was to avoid fighting among themselves and to keep their hearts free of pettiness. These thoughts provided the participants with many things to think about during the lunch together on the second day.

\section{Seeing Oneself and Being Seen}

After lunch, the group saw the videos that had been taken the previous day. The women were greatly amused to see how they looked on film for the first time ever. Some were embarrassed. Namrataben asked them to take note of how they stood, how they narrated their name, and their place in the video. They wanted to watch the videos again and again and as often as they asked, they were granted permission.

After the videos, the facilitators then initiated a discussion of SEWA's ten questions. All SEWA leaders, she said, need to ask themselves these questions all the time with regard to their work with and on behalf of poor, self-employed women:

- Has women's employment increased?

- Has women's income increased?

- Are the women obtaining nutritious food?

- Has women's health improved?

- Can women raise their children properly?

- Do women have shelter?

- Do women have ownership over asserts (i.e., land, house, tools, equipment, etc.)?

- Has women's organization increased?

- Has there been an increase in the leadership of poor, self-employed women?

- Has women's collective, as well as individual, self-reliance increased?

"If we can successfully answer these ten questions", the senior trainer said, "then we can say that we have done something for poor, self-employed women. These questions are our yard stick, guidelines for the future of the selfemployed workers' movement." 
This presentation was then followed by a discussion of the three circles, which illustrated what it meant to say that two-thirds of the world's work was done by women, and yet women controlled only ten percent of the world's income and owned only one percent of its assets. The participants were asked whether they accepted this position or not, and they all said, "No!" at once, to a woman. "When you come home after the whole day's work," Namrataben asked, "who gives you a glass of water or tea, who bothers about you? We do all the work because we are supposed to do so. But we have to bother about ourselves, begin to value ourselves, our work, and our significant contribution to the Indian economy and society."

"By coming together in SEWA," said Bhanuben, "we have started this road towards change, towards justice." Then, when the senior trainer observed that we have along long way to go, a sea of voices rose in affirmation.

\section{Evaluation}

The last session of the training was devoted to assessing its strengths and weaknesses. The women were asked what they thought about it. Was it useful to them? Did they learn anything new? Or was it too long and tedious? How were they going to use what they had learned? For what purpose? They were urged not just to say "good" but to give critical feedback so that the training session could be made better for other groups of women. Among their comments were the following:

- $\quad$ "I liked the suggestion that we should educate our daughters. I learned how to go deep into these issues. Then only can one understand. Just as when you dig for water, you have to dig deep to find it," remarked one woman.

- $\quad$ Another said, "Sisters, I have been coming to SEWA meetings for years now. But I have never known all these things that we have just learned here."

- "I liked seeing myself on video," said many women.

- $\quad$ "I liked the training because I learned so many new things here, about SEWA, about Gandhiji," said Jeekonben.

- $\quad$ "If I had stayed indoors and had rolled papad I would have not learned anything that I learned here," remarked another.

The evaluation session was followed by the certification ceremony. The excitement was palpable. Faces lit up as one by one their names were called out. These were women who had never been to school, let alone obtained a certificate. As each received the certificate, others cheered and clapped. They were given certificates and a group photograph in a folder. The training then ended with a song. The notes of "We Shall Overcome" in Hindi filled the training room. 
The women joined in where they could, savoring the words and this very new experience of coming together-their first training in SEWA.

\section{Impact}

The first ever SEWA movement training thus came to a close. It was finished. But it had created a legacy for the following decades. This first-ever session showed the way and contributed significantly to the development of other training modules. For example, the drawing sessions created the spirit in women that "If I can draw, I can write" and thus led to the birth of the literacy classes in SEWA. The leadership discussion led to the development of the advanced leadership module, which has provided members with significant insight into leadership issues and thus helped SEWA move forward.

Finally, there have been modifications though the years, even to this first course. Initially all the training classes took place at SEWA Academy, which helped women - who were illiterate and poor and had never had the experience before - get the feel of a formal classroom. In the classroom, they learned many things like discipline, how to maintain order inside the class, how to sit in rows and speak out - not all at once, but one after another. From coming to the training session, entering the training room one by one, removing their shoes and putting them in order, to finding a place to sit and sitting throughout, maintaining proper discipline, each step would be a learning exercise for these women.

But as requests for training started to come from more rural SEWA members, classes had to be held in small villages, outside a strict classroom environment, where maintaining discipline was very difficult. For example, in the countryside many women had to milk the cows at a particular time of the day, and, as cows would not allow others to milk them, class times had to be more flexible. Modifications were even made at the district level. For example, the session on Gandhian values was moved to Gandhi's own Sabarmati Ashram in Gujarat rather than being held at the SEWA Academy. Doing so provided the participants with a field trip, which exposed them to new things and enriched their educational experience.

Despite the changes, all the training sessions still end the same way: with a big round of applause for the participating women, with singing "We Shall Overcome," and with shouting the slogan, "Ham sab ek Hai!" (We are One!), binding all together in a common thread of sisterhood and solidarity. 